\title{
The Role of Factors Affecting the Adoption of Environmentally Friendly Farming Practices: Can Geographical Context and Time Explain the Differences Emerging from Literature?
}

\author{
Daniele Mozzato $^{1}$ (i), Paola Gatto 2 (1) , Edi Defrancesco ${ }^{2, *}$ (1) Lucia Bortolini $^{2}$ (i), \\ Francesco Pirotti 2 (D), Elena Pisani 2 (D) and Luigi Sartori 2 (D) \\ 1 Land Environment Resources and Health (LERH) PhD Program—Land Environment Agriculture and \\ Forestry (LEAF) Department, University of Padova, Via dell'Università, 16, 35020 Legnaro (PD), Italy; \\ daniele.mozzato.1@phd.unipd.it \\ 2 Land Environment Agriculture and Forestry (LEAF) Department, University of Padova, Via dell'Università, \\ 16, 35020 Legnaro (PD), Italy; paola.gatto@unipd.it (P.G.); lucia.bortolini@unipd.it (L.B.); \\ francesco.pirotti@unipd.it (F.P.); elena.pisani@unipd.it (E.P.); luigi.sartori@unipd.it (L.S.) \\ * Correspondence: edi.defrancesco@unipd.it; Tel.: +39-049-827-2721
}

Received: 31 July 2018; Accepted: 29 August 2018; Published: 31 August 2018

\begin{abstract}
Environmentally Friendly Farming Practices (EFFPs) are tools aimed at providing ecosystem services or mitigating the environmental impacts of intensive agriculture. A large literature has explored the factors affecting the adoption of EFFPs by farmers. However, opposite effects of several factors on uptake have often emerged. We carried out a qualitative meta-analysis of the literature seeking to identify some geographical and temporal trends that can provide a rationale to explain these opposite results. To reach this goal, we analysed the literature and classified the following factors affecting farmers' behaviour according to the theory of reasoned action and planned behaviour: farm, farmer, informational, and social factors. Our perspective in exploring the existing literature shows that the geographical context and the temporal period under analysis, considered as different adopters' cohorts, can explain most of the opposite effects. For example, while the different effects of farm structural factors show specific geographical patterns, those of the management and economic factors follow temporal trends. The impact of some farmers' socio-demographical characteristics and some social factors can be explained in terms of both geographical context and time. The broad trends we found cast light on the importance of further research adopting the same methodological approach in different geographical contexts and under a temporal perspective.
\end{abstract}

Keywords: environmentally friendly farming practices; adoption; uptake; factors affecting farmers' behaviour; theory of reasoned action and planned behaviour; geographical context; temporal trend

\section{Introduction}

Environmentally Friendly Farming Practices (EFFPs) can be meant as a set of farming practices aimed at mitigating critical environmental issues connected to intensive agriculture or at increasing the provision of agricultural ecosystem services. These practices can be directed towards different resources of the farming environment, like soil, water, landscape, habitat, and biodiversity. In recent decades, specific EFFPs have been proposed as a tool for reducing diffuse soil and water pollution, contrasting landscape simplification and loss of habitats and improving ecological quality [1]. In many countries, EFFPs are supported by policy initiatives providing financial incentives to stimulate farmers' participation. However, research in this field [2-7] has shown that a full and effective implementation 
of EFFPs goes far beyond financial support and needs to be based on a change in farmers' behaviour and intentions. This change, in turn, is affected by a wide range of factors [1].

Understanding the role of these factors is a challenge for agricultural economics research, as shown by the high number of works published in recent decades. Until the turn of the century, studies were mainly focused on the farm structure and farmers' socio-demographic characteristics, while later works have highlighted that the adoption of EFFPs is affected by a much larger number of factors, amongst which motivations and attitudes are very important [8-19]. Recent research has endeavoured to explore the role of social capital $[14,20,21]$, especially the interpersonal relationships amongst farmers and their networks. In addition, spatial modelling techniques are today enabling the inclusion of the spatial attributes of factors and a better understanding of the diffusion patterns on the adoption of EFFPs [22-24].

The rich scientific literature on the factors affecting farmers' behaviours has been reviewed by several authors, who have focused on a single EFFP or on some of them: soil [25-29] and/or water [26,27,30-34] conservation practices, organic farming [35,36], low-input farming systems [37-39], biodiversity protection practices [40], and practices with multiple objectives [41-44].

This literature covers different contexts, e.g., developed and developing countries, areas where financial support for EFFPs is in place or not, etc., and also analyses different time periods. When reviewing it in depth, differences-sometimes even contrasts-in the role played by several factors in affecting farmers' behaviour emerge, i.e., some authors found that a given factor has positive effects on the adoption of EFFPs, while other authors found it has negative effects.

We hypothesise that a rationale for explaining these contrasting results can be found by analysing them in the perspective of different geographical contexts and/or different famers' cohorts of early and late adopters. To this end, our paper has reviewed global literature seeking to identify possible geographical and temporal trends capable of explaining such differences. Our qualitative meta-analysis of the literature aims to understand the effect of factors affecting the adoption of EFFPs under a holistic approach-i.e., independently of the specific EFFP nature-with an original perspective so far only partially explored, and not by many authors [35,45-48].

\section{Materials and Methods}

In our analysis, we referred to the theory of reasoned action and planned behaviour [49,50], the most referential theory used to understand how individuals' behaviours can be influenced by their motivations and attitudes. With reference to the context we analysed, this theory postulates that farmers' attitudes and behaviour towards the adoption of EFFPs are related to their beliefs. These, in turn, are affected by a set of background factors [51]. Mettepenningen et al. [52] have distinguished four categories of background factors for the uptake of agri-environment schemes: (i) farm factors; (ii) farmer factors; (iii) informational factors; and (iv) social factors.

We adopted this classification with several adaptations, i.e. we introduced further distinctions within both farm and farmer factors, as reported in Figure 1. In addition, we considered some spatial factors influencing the adoption of EFFPs, explored now by an emerging strand of literature-see, for example, [22-24]. We included some of these spatial factors-i.e., farm proximity to, for example, urban centres and main roads, and the localisation of the farm-among the structural characteristics of the farm. Another social factor is the number of neighbouring farms adopting a given EFFP. This is often interpreted as learning from other farmers, receiving information, and sharing experiences grounded on the social network of the farmer, so it may be included among either informational or social factors. Following [53,54], we classified it under social factors (Figure 1). 


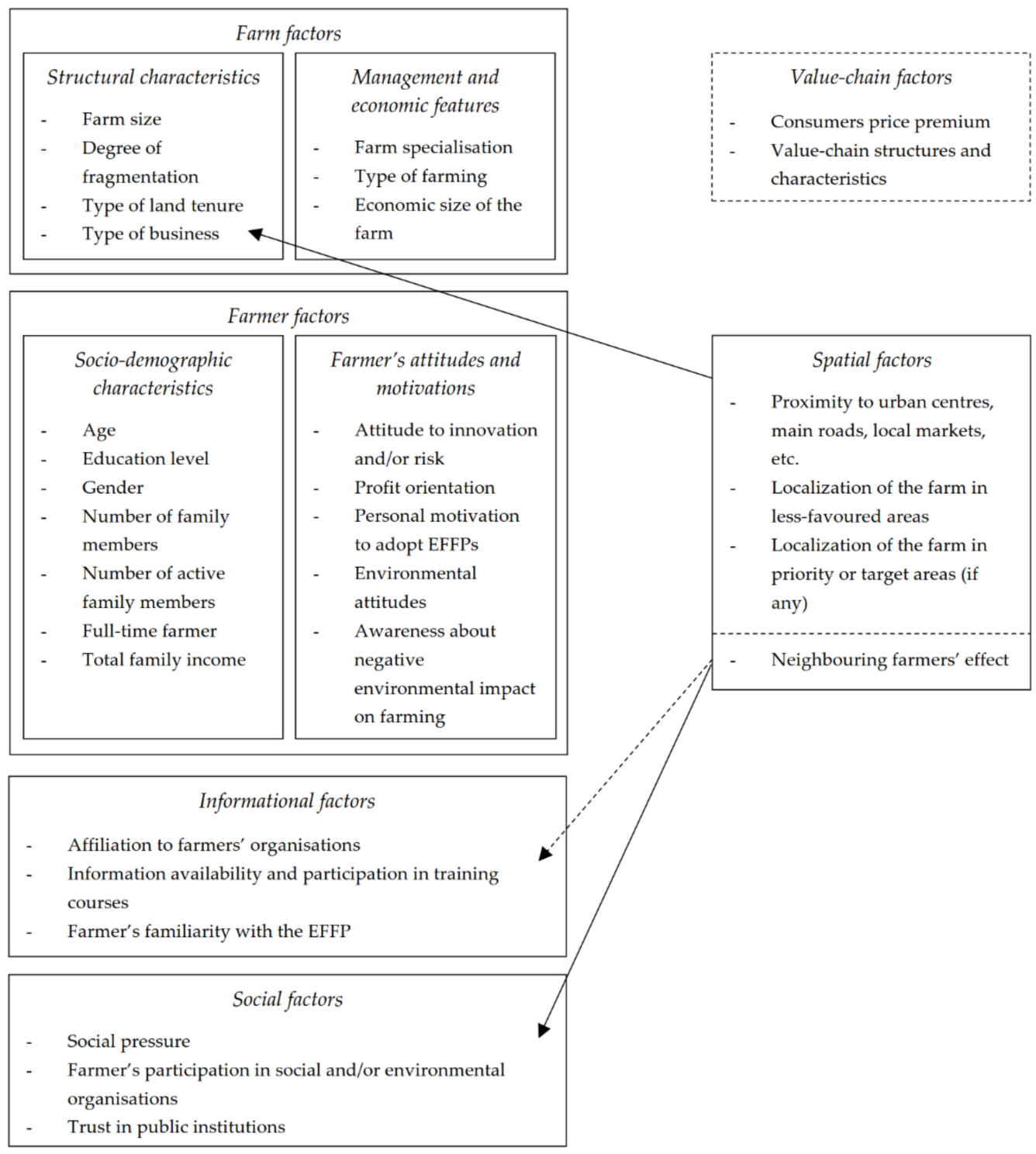

Figure 1. Background factors affecting farmers' adoption of Environmentally Friendly Farming Practices (EFFPs).

The adopted methodological framework disregards a set of value-chain-related factors which may affect farmers' choices on adoption of some EFFPs when consumers are willing to pay a price premium for agri-food products produced by farmers adopting, for example, organic or low-input farming practices. Price premiums are generally observed when consumers perceive these food products as both healthier and less harmful to the environment than the conventional ones (see [55] for a review), when EFFP-linked products are sold through short chains [56], and/or when territorial-specific alternative value chains are created thanks to EFFPs [57-59]. Nevertheless, the impact of price premiums on farmers' decisions largely depends on several issues, like the structure of the supply chains and the different bargaining power held by firms at the different stages of the chain which affects the magnitude of the value transmission along the chain upwards to the farmers [60]. Moreover, other complex vertical relationships established in the value-chain may affect farmers decisions on some EFFPs adoption, like the effect of public food quality certification schemes (e.g., the Italian regional schemes for integrated pest management), the quality standards, and the code of practices $[61,62]$ established by the processors and more often by large-scale retailers, generally in a multidimensional buyers power context (see [63-65] for a review). Despite the weight 
value-chain-related factors may have in farmers' decisions to adopt EFFPs, or at least some of them, no papers including these factors in adoption models were found: hence, we mentioned them in our framework (dashed box in Figure 1) but could not include them in our review.

We extensively reviewed the Scopus, Web of Science, and Google Scholar databases covering the new millennium and the literature of the late 1990s. We scrutinised 350 works, but limited our analysis to those having estimated a model on the adoption of EFFPs and reporting the reference period for the analysed data. After this selection, we ended up with 108 research papers and 17 conference proceedings.

We then attributed the studies to seven areas according to their geographical location: Northern Europe (NE), Southern Europe (SE), North America (NA), Central-South America (SA), Africa (AF), Asia (AS), and Oceania (OC). The distribution of analysed papers according to the geographical areas is the following: NE: $25 \%$; SE: $21 \%$; NA: $10 \%$; SA: $8 \%$; AF: $20 \%$; AS: $11 \%$; and OC: $5 \%$. A more detailed geographical scale for Europe is justified by the higher availability of papers.

Finally, when selecting the factors to be considered in our review, we took into account only those reporting positive or negative effects on the adoption of EFFPs that were statistically significant.

\section{Results}

The outcomes of our qualitative meta-analysis aiming at explaining the contrasting results in terms of geographical context and temporal trends are summarised in Tables 1-6, while the specific references to the reviewed literature are accounted for in Appendix A. The trends we found are common to all the EFFPs analysed, with very few exceptions.

\subsection{Farm Factors}

\subsubsection{Structural Characteristics of the Farm}

- Farm size: The vast majority of the analysed research highlights a positive effect for large-sized farms on the adoption of EFFPs. In AF, and especially for soil and water conservation practices [12,66-70], this positive role is often linked to higher flexibility in terms of decision-making, greater access to resources, and more opportunities to test new practices on small sample plots [71,72]. In NE and SE, however, a negative effect is found in some cases, related to the higher profit-orientation of larger farms compared with smaller ones, or to the ease of management of smaller farms in the case of labour-intensive EFFPs [7,46,73-77].

- Degree of fragmentation: In NA and AS, a high degree of fragmentation negatively affects the probability that a farmer will adopt EFFPs [78], due to the increased management complexity [79] or to the requirements of using contiguous plots of farmland for some conservation programmes [80].

- Ownership of land: In AF and AS, owners are more willing to adopt EFFPs [81-85] compared with renters. Indeed, in these geographical contexts, well-defined ownership rights [86] and the security of land access [87] are crucial preconditions to the adoption of EFFPs [88]. Meanwhile, in NE, SE, and NA, different results occur depending on the specific EFFP considered.

- Sole proprietorship farm: A sole proprietorship structure facilitates farmers' decision-making towards the adoption of EFFPs in AS [79]. Instead, in NE, SE, and NA, more complex business types play a positive role compared with sole proprietorship $[89,90]$ due to a higher managerial ability paired with a lower individual liability [91].

- Proximity: Farm proximity to urban centres [66,80,92,93], main roads [84,87], local markets [3,66,83,94], and product aggregation/processing centres [66,95] is explored by the literature. In AF and AS, proximity to local markets and aggregation/processing centres positively affects the uptake of EFFPs, thanks to the technical information and assistance farmers receive there $[66,78,83,84,94,96]$. However, some opposite results emerge in $\mathrm{AF}$, mainly in relation to main roads $[3,66]$ and urban 
centres [66], where farmers are more profit-oriented. In NE for organic farming [93,97] and in NA, the majority of papers report a negative proximity effect.

- Localisation: In NE and SE, where rural development policies define target areas for many EFFPs, this factor plays a positive role as expected [77,89,90,98-102]. Farm localisation within less-favoured areas has a predominantly positive effect in NE [89,103] and SE [24,100,104-110]; however, some papers highlight negative results in SE $[76,99,100,110,111]$, due to the fact that the scarcity of infrastructures and services-which characterises marginal areas-increases transaction costs and discourages the adoption of EFFPs [95].

Table 1. Main results for the structural characteristics of the farm (NE: Northern Europe; SE: Southern Europe; NA: North America; SA: Central-South America; AS: Asia; AF: Africa; OC: Oceania).

\begin{tabular}{ccc}
\hline \multirow{2}{*}{ Structural Characteristics of the Farm } & \multicolumn{2}{c}{ Effect on Adoption of EFFPs } \\
\cline { 2 - 3 } & \multicolumn{1}{c}{+} \\
\hline Farm size & $\mathrm{NE}, \mathrm{SE}, \mathrm{NA}, \mathrm{AF}, \mathrm{AS}, \mathrm{OC}$ & $\mathrm{NE}, \mathrm{SE}$ \\
Degree of fragmentation & & $\mathrm{NA}, \mathrm{AS}$ \\
Ownership of land & $\mathrm{NE}, \mathrm{SE}, \mathrm{NA}, \mathrm{AF}, \mathrm{AS}$ & $\mathrm{NE}, \mathrm{SE}, \mathrm{NA}$ \\
Sole proprietorship farm & $\mathrm{AS}$ & $\mathrm{NE}, \mathrm{SE}, \mathrm{NA}$ \\
Proximity & $\mathrm{AF}, \mathrm{AS}$ & $\mathrm{NE}, \mathrm{NA}, \mathrm{AF}$ \\
Localisation in target areas & $\mathrm{NE}, \mathrm{SE}$ & $\mathrm{SE}$ \\
Localisation in less-favoured areas & $\mathrm{NE}, \mathrm{SE}$ & \\
\hline
\end{tabular}

3.1.2. Management and Economic Features of the Farm

- Farm specialisation and type of farming: The effect of a high level of specialisation has been analysed particularly in NE and SE. Here, a trend perspective allows us to give a good explanation of the opposite results provided by the literature: taking into account that, in several cases, the adoption of EFFPs implies a farm diversification [112], early EFFP adopters are generally mixed farms $[14,75,99,103,111,113,114]$, while late adopters are more specialised [74,106-108,115]. Both in NE and in SE, a specialisation in permanent crops positively affects the adoption of EFFPs $[45,114,116-118]$, while the effect of specialisation in livestock differs between SE farms, where the effect is positive $[14,99,106-108,111,114,117-120]$, and NE farms, where the effect is negative $[93,103,113]$.

- Economic size of the farm: This factor also has been analysed almost solely in NE and SE. In both geographical areas, a temporal trend is detected: early adopters are represented by large farms in economic terms $[103,106-108,121]$, while more recent adoption of EFFPs is particularly diffuse among farms in smaller economic size classes [14,76,99,111].

Table 2. Main results for the management and economic features of the farm (NE: Northern Europe; SE: Southern Europe; NA: North America; SA: Central-South America; AS: Asia; AF: Africa; OC: Oceania).

\begin{tabular}{ccc}
\hline \multirow{2}{*}{$\begin{array}{c}\text { Management and Economic } \\
\text { Features of the Farm }\end{array}$} & \multicolumn{2}{c}{ Effect on Adoption of EFFPs } \\
\cline { 2 - 3 } & + & - \\
\hline Farm specialisation & late adopters: NE, SE & early adopters: NE, SE \\
Livestock farm & SE & NE \\
Economic size of the farm & early adopters: NE, SE & late adopters: NE, SE \\
\hline
\end{tabular}

\subsection{Farmer Factors}

\subsubsection{Socio-Demographic Characteristics}

- Age: If we exclude AF, a clear temporal trend in the farmers' age effect is revealed: while younger farmers prevail among the early EFFPs adopters $[11,45,73,75,84,90,101,104-108,113,119,121-127]$, 
older farmers act as followers-i.e., late adopters [85,89,95,116,117,120,128-134]. In AF, contrasting results emerge, however: younger farmers seem more prone to implement soil and water conservation practices, particularly in recent years $[3,4,67-69,81,83,94]$.

- Education level: Regardless of the geographic context, literature agrees on the evidence that farmers who are more educated - and therefore more informed about environmental threats linked to agricultural production—are more inclined to adopt EFFPs $[11,67,68,72,75,79,81,85,93,94,100-102$, 109,114-116,120,121,127,130,131,135-140].

- Gender: In NE, SE, and NA, the reviewed works show that female farmers have a higher motivation to adopt EFFPs, especially organic farming $[53,73,74,115,141]$. In AF, where mostly soil and water conservation practices have been considered, a temporal trend can be detected: while male farmers are mainly early adopters $[67,139,142]$, women are late adopters $[3,69,70,94]$.

- Number of family members and number of active family members: These indicators are often used as a proxy of family labour availability within the farm. In NE, the number of family members plays a positive effect in particular for labour-intensive EFFPs like organic farming $[46,73,126,141,143]$. In AF, the number of active family members has a positive effect only for early adopters $[12,67,87,96,144]$ : this positive effect is explained by literature both in terms of family labour availability and the opportunity of sharing management decisions with other family members, which characterises innovator farmers in this context [125]. Conversely, in SE, SA, and for AF-AS late adopters, the effect of both factors is negative when the adoption of EFFPs implies an extensification of the farming system, which causes a reduction in the need for on-farm labour in contexts where off-farm job opportunities are limited $[13,14,111,139,145,146]$. Authors explain the negative effect of family size for AF-AS late adopters also with the fact that farmers perceive EFFPs as restrictions they impose on the future management of their farms [12,70,78,127,132] or on their heirs [147].

- Full-time farmer: A clear temporal trend is observed for NE, SE, and NA. This factor has a positive effect for early adopters $[92,99,101,116,124,148]$, as EFFPs require operational and managerial skills, and a negative one for the followers $[77,98,100,131]$, especially for organic farming. A positive effect is observed also in SA and AF [81,94,143], regardless of the time period.

- Total family income and off-farm income: Total family income shows mixed effects that can be explained when taking into account geographical context. In NE and SE, where in the majority of cases the adoption of EFFPs is financially supported by specific policies, low family income plays in favour of the adoption of EFFPs $[97,113,120]$. Conversely, in AF, a high total family income facilitates the adoption of EFFPs which negatively impact on the farm income, like soil conservation practices [12,83,96], or low-input farming systems [149]. Regardless of geographical context, most of the authors explain the positive effect of total family income by considering that income from off-farm activities reduces the risk from adopting EFFPs $[13,113,134,150]$.

Table 3. Main results for socio-demographic characteristics of farmer (NE: Northern Europe; SE: Southern Europe; NA: North America; SA: Central-South America; AS: Asia; AF: Africa; OC: Oceania).

\begin{tabular}{ccc}
\hline \multirow{2}{*}{ Socio-Demographic Characteristics of Farmer } & \multicolumn{2}{c}{ Effect on Adoption of EFFPs } \\
\cline { 2 - 3 } Age & AF; late adopters: NE, NA, SA, AS & AF; early adopters: NE, SE, SA, AS \\
\hline Education level & NE, SE, NA, SA, AF, AS, OC & \\
\hline Gender (female) & NE, SE, NA; late adopters: AF & early adopters: AF \\
\hline Number of family members & NE & late adopters: AF, AS \\
\hline Number of active family members & early adopters: AF & SE, SA; late adopters: AF \\
\hline Full-time farmer & SA, AF; early adopters: NE, SE, NA & late adopters: NE, SE, NA \\
\hline Total family income and off-farm income & AF & NE, SE
\end{tabular}




\subsubsection{Attitudes and Motivations}

- Attitude to innovation and/or risk: The literature has analysed the effect of farmers' attitudes to introducing innovation using proxies like the use of the internet and software for farm management [95,114,126,131], or farmers' willingness to try new farming technologies [79]. The positive effects on the adoption of EFFPs of both an attitude towards innovation $[73,79,95,114,120,126,130,131,151]$ and risk-oriented management $[7,46,77,115,151-153]$ emerges regardless of geographical context.

- Profit orientation: Profit-oriented farmers are generally more prone to adopting EFFPs in any geographical context $[54,74,110,116,153-155]$. Few opposite results emerge only in NE and SE for organic farming $[46,93,110]$.

- Personal motivations to adopt EFFPs: These factors are often proxied by unobserved factors identified through factor analysis or principal component analysis (see, for example, Micha et al. [110]). Personal motivations include, for example, health or financial concerns; the farmer's inclination to produce in a more sustainable way or, in general, to test new farming techniques; or the farmer's desire to implement farming systems more fitted to his/her beliefs. The positive effect of personal motivations is widely recognised $[2,20,53,93,110,127,141,156-160]$, independently of geographical context and reference period.

- Environmental attitudes: Proxies of environmental attitudes (e.g., concerns about local or global environmental threats, awareness of the need to protect endangered natural habitats or the positive environmental impact of EFFPs, and simultaneous adoption of more than one EFFP) are particularly explored in NE and SE, where they positively affect the adoption of EFFPs $[7,11,46,53,73,77,90,93,116,119,120,129,130,156,157,161]$; similar results are observed also in NA, AF, AS, and OC $[16,79,92,151,162-164]$.

- Awareness about negative environmental impact on farming: This factor has been particularly analysed in NA, AF, and AS for soil and water conservation practices $[6,12,20,72,79,81,83,94,125,153]$ and in $\mathrm{SE}$ for organic farming. Our review shows that farmers are more prone to adopting EFFPs when they are more conscious that their farming may be threatened by environmental problems.

Table 4. Summary of the main results for attitudes and motivations of farmer (NE: Northern Europe; SE: Southern Europe; NA: North America; SA: Central-South America; AS: Asia; AF: Africa; OC: Oceania).

\begin{tabular}{ccc}
\hline \multirow{2}{*}{ Attitudes and Motivations of Farmer } & \multicolumn{2}{c}{ Effect on Adoption of EFFPs } \\
\cline { 2 - 3 } & \multicolumn{1}{c}{-} \\
\hline Attitude to innovation and/or risk & NE, SE, NA, AF, AS, OC & NE \\
Profit orientation & NE, SE, NA, AF, OC & \\
Personal motivations to adopt EFFPs & NE, SE, AF, AS, OC & \\
Environmental attitudes & NE, SE, NA, AF, AS, OC & \\
Awareness about negative & SE, NA, AF, AS \\
environmental impact on farming & \\
\hline
\end{tabular}

\subsection{Informational Factors}

- Affiliation to farmers' organisations, e.g., farmers' unions and producers' organisations: The information and technical advice these organisations provide generally plays a positive role in the adoption of EFFPs regardless of geographical context. However, some opposite results are found for early organic farming adopters in NE [73,141] and in some SE countries [111,130].

- Information availability and participation in training courses: The former triggers the adoption of EFFPs $[3,20,68,75,81-83,94,104,120,139,144,149,158,165-167]$ independently of geographical and temporal context. The latter provides similar results $[5,72,86,168]$, training courses being necessary capacity building tools for EFFPs requiring more expertise [79].

- Farmer's familiarity with the EFFP: This factor is proxied by several variables, for example, the number of years the farmer has been aware of another adopter in the area $[137,167]$, the number 
of years since he/she firstly adopted the EFFP [78,90], or, more generally, his/her experience of EFFPs $[11-14,45,100,113,120,124,135,142,163]$. The largest majority of the reviewed papers reports a positive effect for this factor.

Table 5. Summary of the main results for informational factors (NE: Northern Europe; SE: Southern Europe; NA: North America; SA: Central-South America; AS: Asia; AF: Africa; OC: Oceania).

\begin{tabular}{ccc}
\hline Informational Factors & \multicolumn{2}{c}{ Effect on Adoption of EFFPs } \\
\cline { 2 - 3 } & \multicolumn{1}{c}{+} & - NE, SE \\
\hline $\begin{array}{c}\text { Affiliation to farmers' organisations } \\
\text { Information availability and participation in training courses } \\
\text { Farmer's familiarity with the EFFP }\end{array}$ & NE, SE, SA, AF, AS, OC & \\
\hline
\end{tabular}

\subsection{Social Factors}

- Social pressure: According to the theory of reasoned action and planned behaviour, social pressure also affects individual behaviour [169]. In the context of our analysis, few papers study this factor, and they use different proxies, i.e., farmer's perception of his/her role in the society $[134,156,170]$, the influence of peers $[115,159,170]$, and appreciation by neighbours [143]. These few papers find positive effects on the adoption of EFFPs in NE, SE, SA, and AS [115,134,143,156]. In OC [159], influence by peers negatively affects the willingness to adopt EFFPs only among those farmers whose behaviour is mainly driven by stewardship, lifestyle, and social motivations. In NA, one paper [170] explores social pressure in a time perspective, showing the positive effect of community pressure on the adoption of EFFPs for late rather than for early adopters.

- Farmer's participation in social and/or environmental organisations: Regardless of the analysed geographical context, this factor-as a proxy of farmers' willingness to network-acts as a catalyst for the adoption of EFFPs by farmers $[14,133,143,157]$ thanks to the social support they receive. However, in AS, this occurs only when farmers are men [127].

- Trust in public institutions: Few recent studies consider this factor. Even though Polman and Slangen [21] highlight its general positive effect on the adoption of EFFPs, opposite results are reported for organic farming in one SE country [110] and in AF [3,83], where EFFPs are mostly promoted by private institutions, which are perceived as less corrupted.

- Neighbouring farmers' effect, proxied by the number of neighbouring farms that adopt the EFFP: a nascent group of studies agrees on the positive effect of the adoption of EFFPs by neighbouring farms on the farmers' EFFP uptake. This effect is explained as a consequence of learning from other farmers, receiving information, sharing experiences, and imitation among neighbouring farmers $[20,24,53,121]$. This proximity effect is positive regardless of geographical context $[70,89,90,165]$.

Table 6. Summary of the main results for social factors (NE: Northern Europe; SE: Southern Europe; NA: North America; SA: Central-South America; AS: Asia; AF: Africa; OC: Oceania).

\begin{tabular}{ccc}
\hline Social Factors & \multicolumn{2}{c}{ Effect on Adoption of EFFPs } \\
\cline { 2 - 3 } & NE, SE, SA, AS; late adopters: NA & OC; early adopters: NA \\
\hline Social pressure & NE, SA, AS & AS \\
\hline $\begin{array}{c}\text { Farmer's participation in social and/or } \\
\text { environmental organisations }\end{array}$ & & SE, AF \\
\hline Trust in public institutions & NE, SE, SA, AF, AS & \\
\hline Neighbouring farmers' effect & & \\
\hline
\end{tabular}




\section{Discussion and Conclusions}

The large strand of literature on factors affecting the adoption of EFFPs by farmers often reports contrasting results on their effects. This paper analyses these opposite results under a comprehensive approach which includes a large range of EFFPs and provides a rationale for explaining most of the observed differences by taking into account the geographical contexts and temporal periods under analysis.

For farm structural factors, geographical context can explain more than one difference. For example, on a worldwide basis, larger farms are more prone to adopting EFFPs, but this does not occur in Northern and Southern Europe for labour-intensive EFFPs. Ownership of land and sole proprietorship are positive crucial factors in developing and recently developed countries in Africa and Asia, where well-defined ownership rights and the security of land access are essential prerequisites to the adoption of EFFPs. Conversely, in developed countries in Northern and Southern Europe and North America, more complex business types facilitate the adoption of EFFPs. In terms of temporal dynamics, our results highlight that this category of factors does not show clear time differences, and this might be explained by the difficulty of modifying farm structures in the short run.

Mainly in the European context, a temporal perspective can explain differences in the effect of management and economic features of farms: while early EFFPs adopters manage unspecialised and more flexible farms with a higher turnover, later adoption of EFFPs is more common in more difficult or risky situations, i.e., in specialised and smaller farms. This may find an explanation in the attempt to fine-tune policy over time.

Overall, geographical and temporal trends vary according to the factor considered in the case of socio-demographic characteristics of the farmer. Amongst others, age shows a clear temporal trend worldwide, except for in African countries: early adopters are generally young farmers while older ones act as followers. High education level of farmers and being female are two factors that, in general, positively affect the adoption of EFFPs without any geographical differentiation or temporal trend. However, we have noticed that in Africa, male farmers are early adopters. A higher availability of family labour, as well as a full-time type of farming, plays a positive role in adoption in all geographical contexts. Only in Southern Europe for full-time farmers and in Africa for family labour availability does a temporal trend emerge, with the positive effect prevailing amongst early adopters.

General temporal trends could not be revealed regarding the attitudes and motivations of farmers on the adoption of EFFPs. The homogeneous positive results reported by the literature can be explained by considering that attitudes and motivations are embedded in the individuals and therefore change only over the very long term. We expected many more geographical differences for this category of factors due to their connection with cultural context, but we found only one opposite result: in the Northern and Southern European context, farmers' attitudes to adopting EFFPs show a negative effect when their decisions are driven mainly by economic motivations.

In general, the crucial positive role of informational factors in affecting the adoption of EFFPs is widely undisputed in all geographical areas considered in our review, and remains unchanged also from a time perspective. The few opposite results are linked to the quality of information provided and the difficulty in implementing a specific EFFP.

There is still limited information for social factors, considered from the fewer number of works when compared with the other factor categories. Amongst social factors, a clear distinction emerges between the factors strictly connected to individual beliefs, i.e., social pressure, trust in government, and participation in social and/or environmental organisations, and the factor expressing the neighbouring farmers' effect, represented by the number of neighbouring farms adopting EFFPs. For the former, geographical differences can be easily explained in terms of different social contexts. For the latter, a positive role is common to all geographical contexts.

Our qualitative meta-analysis shows that geographical context and time are relevant perspectives that can help to explain several differences in the role of factors affecting the adoption of EFFPs emerging from literature. Geographical differences often reflect background, structural, social, 
and economic factors that are rooted in local society and its institutions. These differences are, however, not static but evolve over time, showing converging or diverging trends that are interesting to study. Unlike most of the existing literature which is based on case studies, our analysis adopts a global perspective that goes beyond single EFFPs; thanks to this, it can provide fruitful suggestions on how to orient policy design in specific geographical areas and time periods. There are, however, some caveats to our approach that need to be acknowledged, the main one being linked to the different methodological approaches adopted by the papers we have reviewed. A second limitation lies in the gaps existing in the literature: with reference to the various geographical contexts and time periods, not all the papers have considered an identical set of factors, so data availability is patchy. The broad trends we found open the way for further research adopting a common methodological approach for considering different geographical contexts and cohorts of EFFPs adopters.

Finally, it has to be recalled that the literature on factors affecting the adoption of EFFPs by farmers that we reviewed omits consideration of the increasing role of value-chain-related factors in affecting farmers' decisions about EFFP uptake when the latter affects food quality attributes valued by consumers and/or required by the processors and the retailers. This limitation opens the door to further research integrating, under the theory of reasoned action and planned behaviour, such factors into the constellation of background factors explaining farmers' decisions on adoption of EFFPs.

Author Contributions: D.M., P.G., E.D., L.B., F.P., E.P., and L.S. collected the literature; D.M., P.G., and E.D. designed the structure of the review, analysed the literature and wrote the paper.

Funding: This research was funded by the TESAF Department 'Linda Scattolin' research grant number Dall_FINAC_P14_02.

Acknowledgments: The authors thank the anonymous reviewers for their valuable comments and suggestions for improving earlier versions of the paper.

Conflicts of Interest: The authors declare no conflict of interest.

\section{Appendix A}

Table A1. Geographical and temporal analysis of the effect of the factors considered in the reviewed research papers (NE: Northern Europe; SE: Southern Europe; NA: North America; SA: Central-South America; AS: Asia; AF: Africa; OC: Oceania—the period of reference for the analysed data is reported before the citations).

\begin{tabular}{|c|c|c|}
\hline \multirow{2}{*}{ Background Factors } & \multicolumn{2}{|c|}{ Effect on Adoption of EFFPs } \\
\hline & + & - \\
\hline \multicolumn{3}{|c|}{ Structural Characteristics of the Farm } \\
\hline \multirow{7}{*}{ Farm size } & $\begin{array}{l}\text { NE: } 1994 \text { [103]; 1994-97 [171]; } \\
\text { 1995-2010 [113]; } 2003 \text { [93]; } 2004 \text { [89]; } \\
2006 \text { [116] }\end{array}$ & $\begin{array}{l}\text { NE: } 1996 \text { [73]; } 1999 \text { [11]; 2004-08 [74]; } \\
2008[7,46]\end{array}$ \\
\hline & $\begin{array}{l}\text { SE: } 2000-15 \text { [90]; } 2004 \text { [119]; } \\
2010[100,114]\end{array}$ & $\begin{array}{l}\text { SE: 2000-03 [172]; } 2003 \text { [105]; } \\
2008 \text { [77]; 2008-09 [109]; } 2010 \text { [76] }\end{array}$ \\
\hline & $\begin{array}{l}\text { NA: } 1996 \text { [101]; } 1997 \text { [6]; } 1999 \text { [80]; } \\
2003 \text { [5,92]; 2007-09 [131] }\end{array}$ & NA: 2004 [95] \\
\hline & SA: 1996 [173]; 2002 [86]; 2007 [165] & SA: 2008 [1] \\
\hline & $\begin{array}{l}\text { AF: 1996-2000 [66]; } 2000 \text { [12]; } 2002 \text { [67]; } \\
\text { 2002-03 [71]; } 2003 \text { [68]; 2003-04 [72]; } \\
2008-11 \text { [69]; } 2012 \text { [70] }\end{array}$ & AF: 2010 [83] \\
\hline & AS: 2006 [78]; 2007 [20]; $2010[79,133]$ & AS: 2012 [140] \\
\hline & OC: 2003 [137]; 2005 [168] & \\
\hline
\end{tabular}


Table A1. Cont.

\begin{tabular}{|c|c|c|}
\hline \multirow{2}{*}{ Background Factors } & \multicolumn{2}{|c|}{ Effect on Adoption of EFFPs } \\
\hline & + & - \\
\hline \multirow{2}{*}{ Degree of fragmentation } & & NA: 1999 [80] \\
\hline & & AS: 2006 [78]; 2010 [79] \\
\hline \multirow{5}{*}{ Ownership of land } & NE: 1994 [103] & NE: 1997 [122]; 2014 [98] \\
\hline & SE: 2003 [105]; 2004 [119]; 2005-06 [13] & SE: 2005 [106-108]; 2006 [99] \\
\hline & NA: 1991/96/2001/06 [91]; 2006-07 [154] & NA: 2006-07 [154] \\
\hline & AF: 2002 [81]; 2008 [82]; 2010 [83] & \\
\hline & AS: 1995 [84]; 2001-02 [85] & \\
\hline \multirow{3}{*}{ Sole proprietorship farm } & AS: 2010 [79] & NE: 2004 [89] \\
\hline & & SE: $2000-15$ [90] \\
\hline & & NA: 1991/96/2001/06 [91] \\
\hline \multirow{5}{*}{$\begin{array}{l}\text { Proximity to urban } \\
\text { centres, main roads, local } \\
\text { markets, etc. }\end{array}$} & NE: 2003 [93] & NE: 2007 [97]; 2014 [98] \\
\hline & NA: 2003 [92] & NA: 1999 [80]; 2003 [92]; 2004 [95] \\
\hline & SA: 2007 [143] & SA: 1997 [87] \\
\hline & $\begin{array}{l}\text { AF: } 1996-2000 \text { [66]; 1999-2000 [96]; } \\
2009-10 \text { [94]; } 2010 \text { [83] }\end{array}$ & AF: 1996-2000 [66]; 2010 [3] \\
\hline & AS: 1995 [84]; 2006 [78] & \\
\hline \multirow{4}{*}{$\begin{array}{l}\text { Farm localisation within } \\
\text { priority or target areas } \\
\text { (if any) }\end{array}$} & NE: 2004 [89]; 2014 [98] & \\
\hline & $\begin{array}{l}\text { SE: 2000-15 [90]; } 2006 \text { [99]; } 2008 \text { [77]; } 2010 \\
\text { [100] }\end{array}$ & \\
\hline & NA: 1996 [101] & \\
\hline & SA: 1999 [102] & \\
\hline \multirow{4}{*}{$\begin{array}{l}\text { Farm localisation within } \\
\text { less-favoured areas }\end{array}$} & NE: 1994 [103]; 2004 [89] & $\begin{array}{l}\text { SE: } 2006 \text { [99]; } 2009 \text { [111]; } 2010 \text { [76,100]; } \\
2012 \text { [110] }\end{array}$ \\
\hline & $\begin{array}{l}\text { SE: 1994-2004 [104]; } 2003 \text { [105]; } 2005 \\
\text { [106-108]; } 2008 \text { [24]; 2008-09 [109]; } 2010 \\
\text { [100]; } 2012 \text { [110] }\end{array}$ & AF: 2008-11 [69] \\
\hline & NA: 1996 [101] & \\
\hline & AF: 2007 [142] & \\
\hline \multicolumn{3}{|c|}{ Management and Economic Features of the Farm } \\
\hline \multirow{3}{*}{ Farm specialisation } & NE: 2004-08 [74] & NE: 1994 [103]; 1995-2010 [113] \\
\hline & SE: 2005 [106-108]; 2008-09 [115] & $\begin{array}{l}\text { SE: } 1996-97 \text { [75]; } 2006 \text { [14,99]; } \\
2009 \text { [111]; } 2010 \text { [114] }\end{array}$ \\
\hline & & SA: 2008 [1] \\
\hline \multicolumn{3}{|l|}{ Type of farming } \\
\hline \multirow{2}{*}{ Permanent crops } & NE: 2006 [116] & \\
\hline & SE: 2004-10 [117,118]; 2010 [114] & \\
\hline \multirow{4}{*}{ Annual crops } & NE: 1994 [103] & SE: 2006-07 [120] \\
\hline & SE: 2010 [114] & \\
\hline & NA: 2003 [92] & \\
\hline & AF: 1996-2000 [66] & \\
\hline
\end{tabular}


Table A1. Cont.

\begin{tabular}{|c|c|c|}
\hline \multirow{2}{*}{ Background Factors } & \multicolumn{2}{|c|}{ Effect on Adoption of EFFPs } \\
\hline & + & - \\
\hline \multirow{2}{*}{ Fodder crops } & SE: 2003 [105]; 2006-07 [120] & NE: 1994 [103] \\
\hline & NA: 2003 [92] & \\
\hline \multirow[t]{2}{*}{ Livestock farm } & $\begin{array}{l}\text { SE: } 2004 \text { [119]; 2004-10 [117,118]; } 2005 \\
\text { [106-108]; } 2006 \text { [14,99]; 2006-07 [120]; } \\
2009 \text { [111]; } 2010 \text { [114] }\end{array}$ & $\begin{array}{l}\text { NE: } 1994 \text { [103]; 1995-2010 [113]; } \\
2003 \text { [93] }\end{array}$ \\
\hline & NA: 1998 [125]; 2003 [5]; 2007-09 [131] & NA: 2003 [92] \\
\hline \multirow{2}{*}{$\begin{array}{l}\text { Economic size of } \\
\text { the farm }\end{array}$} & NE: 1994 [103] & SE: 2006 [14,99]; 2009 [111]; 2010 [76] \\
\hline & SE: 1997 [121]; 2005 [106-108] & \\
\hline \multicolumn{3}{|c|}{ Socio-Demographic Characteristics of Farmer } \\
\hline \multirow{6}{*}{ Age } & $\begin{array}{l}\text { NE: } 2004 \text { [89]; } 2006 \text { [116]; } 2008 \text { [117,128]; } \\
\text { 2011-12 [129] }\end{array}$ & $\begin{array}{l}\text { NE: 1995-2010 [113]; } 1996 \text { [73]; } 1997 \\
\text { [122]; } 1998 \text { [123]; } 1999 \text { [11]; 2004-08 } \\
\text { [74]; } 2008 \text { [46] }\end{array}$ \\
\hline & SE: 2005-06 [130]; 2006-07 [120] & $\begin{array}{l}\text { SE: 1994-2004 [104]; 1996-97 [75]; } \\
\text { 1997 [121]; 2000-15 [90]; } 2003 \text { [105]; } \\
2004 \text { [119,124]; 2005 [106-108]; } 2006 \\
\text { [14,99]; 2008 [77]; 2008-09 [109]; } 2009 \\
\text { [111]; } 2010 \text { [114] }\end{array}$ \\
\hline & $\begin{array}{l}\text { NA: 1991/96/2001/06 [91]; } 2004 \text { [95]; } \\
\text { 2007-09 [131] }\end{array}$ & $\begin{array}{l}\text { NA: } 1996 \text { [101]; } 1998 \text { [125]; } \\
\text { 2003-04 [126] }\end{array}$ \\
\hline & SA: 2007 [143] & SA: 2004 [136]; 2008 [1] \\
\hline & $\begin{array}{l}\text { AF: 1999-2000 [96]; 2002-03 [71]; 2004-08 } \\
\text { [138]; } 2006 \text { [139]; } 2008 \text { [82]; 2011-12 [149] }\end{array}$ & $\begin{array}{l}\text { AF: } 1994 \text { [144]; } 2002 \text { [67,81]; } 2003 \text { [68]; } \\
2008-11 \text { [69]; 2009-10 [4,94]; } 2010 \text { [83]; } \\
2013 \text { [3] }\end{array}$ \\
\hline & $\begin{array}{l}\text { AS: 2001-02 [85]; } 2006 \text { [132]; } 2010 \text { [133]; } \\
2014 \text { [134] }\end{array}$ & AS: 1995 [84]; 1998 [127] \\
\hline \multirow{7}{*}{ Education level } & NE: 1999 [11]; 2003 [93]; 2006 [116]; & NE: 1996 [53] \\
\hline & $\begin{array}{l}\text { SE: 1996-97 [75]; } 1997 \text { [121]; } 1998 \text { [135]; } \\
\text { 2005-06 [130]; 2006-07 [120]; 2008-09 } \\
{[109,115] ; 2010[100,114]}\end{array}$ & AF: 2009-10 [4]; 2010 [83] \\
\hline & NA: 1996 [101]; 2007-09 [131]; 2008 [16] & AS: 1998 [127]; 2007 [20]; 2014 [134] \\
\hline & $\begin{array}{l}\text { SA: } 1999 \text { [102]; } 2002 \text { [86]; } 2004 \text { [136]; } \\
2007 \text { [165] }\end{array}$ & \\
\hline & $\begin{array}{l}\text { AF: 1996-2000 [66]; } 2002 \text { [67,81]; } 2003 \text { [68]; } \\
\text { 2003-04 [72]; 2004-08 [138]; } 2006 \text { [139]; } \\
\text { 2007 [166]; } 2008 \text { [82]; 2009-10 [94]; } \\
\text { 2011-12 [149] }\end{array}$ & \\
\hline & $\begin{array}{l}\text { AS: } 1995 \text { [84]; } 1998 \text { [127]; 2001-02 [85]; } \\
2010 \text { [79]; } 2012 \text { [140]; 2014 [174] }\end{array}$ & \\
\hline & OC: 2003 [137] & \\
\hline \multirow{5}{*}{ Gender (female) } & NE: 1996 [53,73,141]; 2004-08 [74] & SA: 2007 [165] \\
\hline & SE: 2008-09 [115] & AF: 2006 [139]; $2007[67,142]$ \\
\hline & NA: 1991/96/2001/06 [91] & \\
\hline & $\begin{array}{l}\text { AF: } 2002 \text { [81]; 2008-11 [69]; 2009-10 [94]; } \\
2010 \text { [3]; } 2012 \text { [70] }\end{array}$ & \\
\hline & AS: 1998 [127] & \\
\hline
\end{tabular}


Table A1. Cont.

\begin{tabular}{|c|c|c|}
\hline \multirow{2}{*}{ Background Factors } & \multicolumn{2}{|c|}{ Effect on Adoption of EFFPs } \\
\hline & + & - \\
\hline \multicolumn{3}{|l|}{ Family } \\
\hline \multirow{4}{*}{ Number of family members } & $\begin{array}{l}\text { NE: 1995-2010 [175]; } 1996 \text { [73,141]; } \\
2008 \text { [46] }\end{array}$ & $\begin{array}{l}\text { AF: } 1999-2000 \text { [96]; } 2000 \text { [12]; } \\
\text { 2009-10 [94]; } 2010[3,83]\end{array}$ \\
\hline & SA: 2007 [143] & AS: 1998 [127]; $2006[78,132]$ \\
\hline & $\begin{array}{l}\text { AF: } 2008-11 \text { [69]; 2009-10 [94]; } 2010 \text { [83]; } \\
2012 \text { [70] }\end{array}$ & \\
\hline & AS: 2007 [20] & \\
\hline \multirow{2}{*}{$\begin{array}{l}\text { Number of active family } \\
\text { members }\end{array}$} & SA: 1997 [87] & AF: 2006 [139]; 2010 [83] \\
\hline & $\begin{array}{l}\text { AF: } 1994 \text { [144]; 1999-2000 [96]; } 2000 \text { [12]; } \\
2002 \text { [67] }\end{array}$ & \\
\hline \multicolumn{3}{|l|}{ Labour } \\
\hline \multirow{5}{*}{ Full-time farmer } & NE: 2006 [116] & NE: 2014 [98] \\
\hline & $\begin{array}{l}\text { SE: } 2000 \text { [148]; } 2004 \text { [124]; } 2006 \text { [99]; } \\
2009 \text { [111]; } 2010 \text { [76,114] }\end{array}$ & SE: 2008 [77]; 2010 [100] \\
\hline & NA: 1996 [101]; 2003 [92] & NA: 2007-09 [131] \\
\hline & SA: 2007 [143] & \\
\hline & AF: 2002 [81]; 2009-10 [94] & \\
\hline \multirow[t]{2}{*}{ On-family labour } & & $\begin{array}{l}\text { SE: 2004-10 [117,118]; 2005-06 [13]; } \\
2006 \text { [14,99]; } 2009 \text { [111] }\end{array}$ \\
\hline & & SA: 2002 [86] \\
\hline \multirow{2}{*}{ Off-family labour } & NE: 2014 [98] & SE: 2006 [99] \\
\hline & $\begin{array}{l}\text { SE: } 2003 \text { [105]; } 2006 \text { [99]; } 2009 \text { [111]; } \\
2010 \text { [114] }\end{array}$ & \\
\hline \multicolumn{3}{|l|}{ Income } \\
\hline \multirow{5}{*}{ Total family income } & SA: 2007 [165] & NE: 1995-2010 [113]; 2007 [97] \\
\hline & $\begin{array}{l}\text { AF: 1999-2000 [96]; } 2000 \text { [12]; } 2010 \text { [83]; } \\
\text { 2011-12 [149] }\end{array}$ & SE: 2006-07 [120] \\
\hline & AS: 2014 [174] & NA: 1997 [170] \\
\hline & & SA: 1999 [102] \\
\hline & & AF: 2006 [139] \\
\hline \multirow{5}{*}{$\begin{array}{l}\text { Importance of the off-farm } \\
\text { income on the total } \\
\text { household income }\end{array}$} & NE: 1995-2010 [113]; 2006 [116] & NE: 2006 [116]; 2013 [157] \\
\hline & $\begin{array}{l}\text { SE: 1996-97 [75]; } 2004 \text { [119]; } \\
\text { 2004-10 [117,118]; } 2008 \text { [77] }\end{array}$ & NA: 1999 [80]; 2003 [5] \\
\hline & SA: 1999 [102]; 2002 [86] & SA: 2002 [86] \\
\hline & AF: 2002 [67]; 2010 [3] & AF: 1999-2000 [96] \\
\hline & AS: 2014 [134] & OC: 2005 [168] \\
\hline \multicolumn{3}{|c|}{ Attitudes and Motivations of Farmer } \\
\hline \multirow{5}{*}{ Innovation attitude } & NE: 1996 [73] & \\
\hline & $\begin{array}{l}\text { SE: 2005-06 [130]; 2006-07 [120]; } \\
2010 \text { [114] }\end{array}$ & \\
\hline & $\begin{array}{l}\text { NA: 2003-04 [126]; } 2004 \text { [95]; } \\
\text { 2007-09 [131] }\end{array}$ & \\
\hline & AS: 2010 [79] & \\
\hline & OC: 2006 [151] & \\
\hline
\end{tabular}


Table A1. Cont.

\begin{tabular}{|c|c|c|}
\hline \multirow{2}{*}{ Background Factors } & \multicolumn{2}{|c|}{ Effect on Adoption of EFFPs } \\
\hline & + & - \\
\hline \multirow{4}{*}{ Risk attitude } & $\begin{array}{l}\text { NE: 1981-2008 [7]; 1990-99 [152]; } \\
2008 \text { [46] }\end{array}$ & \\
\hline & SE: 2008 [77]; 2008-09 [115] & \\
\hline & AF: 1996 [153] & \\
\hline & OC: 2006 [151] & \\
\hline \multirow{5}{*}{ Profit orientation } & NE: 2004-08 [74]; 2006 [116]; 2008 [54] & NE: 2003 [93]; 2008 [46] \\
\hline & SE: 2010 [76] & SE: 2012 [110] \\
\hline & NA: 2006-07 [154] & NA: 2003 [92] \\
\hline & AF: 1996 [153] & \\
\hline & OC: 2006 [151] & \\
\hline \multirow{5}{*}{$\begin{array}{l}\text { Personal motivation to } \\
\text { adopt EFFPs }\end{array}$} & $\begin{array}{l}\text { NE: } 1996 \text { [53,141]; } 2003 \text { [93]; } 2009 \text { [156]; } \\
2013 \text { [157] }\end{array}$ & \\
\hline & SE: 2012 [110] & \\
\hline & AF: 2009 [2] & \\
\hline & AS: 1998 [127]; 2007 [20]; 2008 [158] & \\
\hline & OC: 2013 [159] & \\
\hline \multirow{6}{*}{ Environmental attitudes } & $\begin{array}{l}\text { NE: } 1981-2008 \text { [7]; } 1996 \text { [53,73]; } 1999 \text { [11]; } \\
2003 \text { [93]; } 2006 \text { [116]; } 2008 \text { [46]; } 2009 \text { [156]; } \\
\text { 2011-12 [129]; } 2013 \text { [157] }\end{array}$ & NA: 1997 [170] \\
\hline & $\begin{array}{l}\text { SE: 2000-15 [90]; } 2004 \text { [119]; 2005-06 [130]; } \\
\text { 2006-07 [120]; } 2008 \text { [77]; } 2010 \text { [161] }\end{array}$ & \\
\hline & NA: 2003 [92]; 2008 [16] & \\
\hline & AF: 2008 [162]; 2013-14 [163] & \\
\hline & AS: 2008 [164]; 2010 [79] & \\
\hline & OC: 2006 [151] & \\
\hline \multirow{6}{*}{$\begin{array}{l}\text { Awareness about } \\
\text { negative environmental } \\
\text { impact on farming }\end{array}$} & NE: 2006 [116] & NE: 1996 [53] \\
\hline & SE: 1996-97 [75]; 2005-06 [130]; 2008 [77] & \\
\hline & NA: 1997 [6]; 1998 [125] & \\
\hline & $\begin{array}{l}\text { AF: } 1996 \text { [153]; } 2000 \text { [12]; } 2002 \text { [81]; } \\
\text { 2003-04 [72]; 2009-10 [94]; } 2010 \text { [83] }\end{array}$ & \\
\hline & AS: 2007 [20]; 2010 [79] & \\
\hline & OC: 2005 [168] & \\
\hline \multicolumn{3}{|l|}{ Informational Factors } \\
\hline \multirow{4}{*}{$\begin{array}{l}\text { Affiliation to farmers' } \\
\text { organisations }\end{array}$} & $\begin{array}{l}\text { SE: } 2005 \text { [106-108]; } 2006 \text { [14]; } \\
\text { 2006-07 [120] }\end{array}$ & NE: $1996[73,141]$ \\
\hline & SA: 2007 [165] & SE: 2005-06 [130]; 2009 [111] \\
\hline & $\begin{array}{l}\text { AF: } 2002 \text { [81]; 2003-04 [72]; 2009-10 [4,94]; } \\
2010[3,83]\end{array}$ & \\
\hline & AS: 1995 [84]; $2010[79,133]$ & \\
\hline
\end{tabular}


Table A1. Cont.

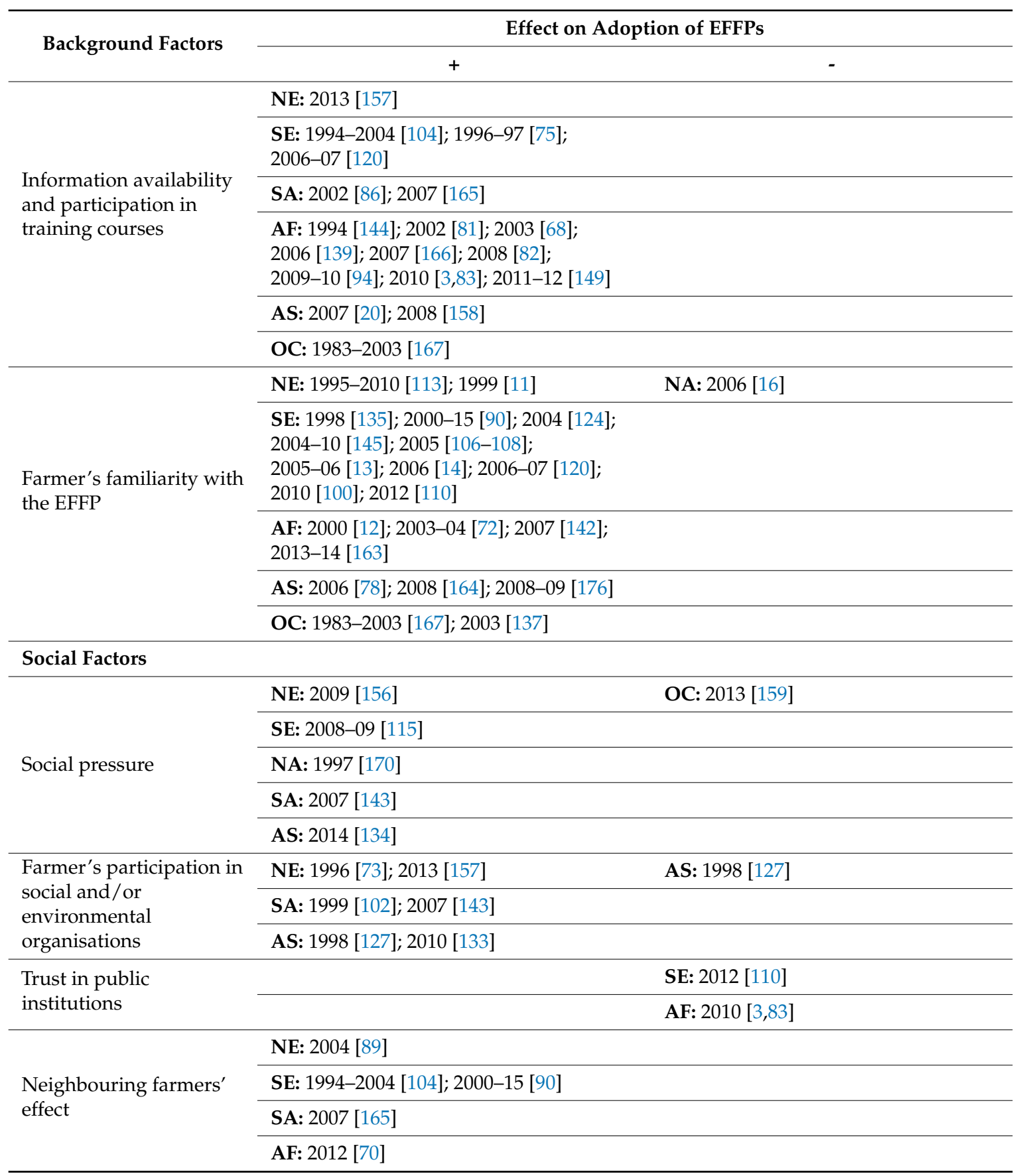

\section{References}

1. Blazy, J.-M.; Carpentier, A.; Thomas, A. The willingness to adopt agro-ecological innovations: Application of choice modelling to Caribbean banana planters. Ecol. Econ. 2011, 72, 140-150. [CrossRef]

2. Friedlander, L.; Tal, A.; Lazarovitch, N. Technical considerations affecting adoption of drip irrigation in sub-Saharan Africa. Agric. Water Manag. 2013, 126, 125-132. [CrossRef]

3. Teklewold, H.; Kassie, M.; Shiferaw, B. Adoption of multiple sustainable agricultural practices in rural Ethiopia. J. Agric. Econ. 2013, 64, 597-623. [CrossRef]

4. Nyanga, P.H. Factors Influencing Adoption and Area under Conservation Agriculture: A Mixed Methods Approach. Sustain. Agric. Res. 2012, 1, 27. [CrossRef] 
5. Yiridoe, E.K.; Atari, D.O.A.; Gordon, R.; Smale, S. Factors influencing participation in the Nova Scotia Environmental Farm Plan Program. Land Use Policy 2010, 27, 1097-1106. [CrossRef]

6. Upadhyay, B.M.; Young, D.L.; Wang, H.H.; Wandschneider, P. How do farmers who adopt multiple conservation practices differ from their neighbors? In Proceedings of the AAEA and WAEA 2002 Annual Meeting, Long Beach, CA, USA, 28-31 July 2002; p. 21.

7. Läpple, D. Adoption and Abandonment of Organic Farming: An Empirical Investigation of the Irish Drystock Sector. J. Agric. Econ. 2010, 61, 697-714. [CrossRef]

8. Beedell, J.; Rehman, T. Using social-psychology models to understand farmers' conservation behaviour. J. Rural Stud. 2000, 16, 117-127. [CrossRef]

9. Wilson, G.A.; Hart, K. Financial imperative or conservation concern? EU farmers' motivations for participation in voluntary agri-environmental schemes. Environ. Plan. A 2000, 32, 2161-2185. [CrossRef]

10. Wilson, G.A.; Hart, K. Farmer Participation in Agri-Environmental Schemes: Towards Conservation-Oriented Thinking? Sociol. Rural. 2001, 41, 254-274. [CrossRef]

11. Vanslembrouck, I.; Huylenbroeck, G.; Verbeke, W. Determinants of the Willingness of Belgian Farmers to Participate in Agri-environmental Measures. J. Agric. Econ. 2002, 53, 489-511. [CrossRef]

12. Tadesse, M.; Belay, K. Factors influencing adoption of soil conservation measures in Southern Ethiopia: The case of Gununo area. J. Agric. Rural Dev. Trop. Subtrop. 2004, 105, 49-62.

13. Defrancesco, E.; Gatto, P.; Runge, F.; Trestini, S. Factors affecting farmers'participation in agri-environmental measures: A northern Italian perspective. J. Agric. Econ. 2008, 59, 114-131. [CrossRef]

14. Pascucci, S.; De-Magistris, T.; Dries, L.; Adinolfi, F.; Capitanio, F. Participation of Italian farmers in rural development policy. Eur. Rev. Agric. Econ. 2013, 40, 605-631. [CrossRef]

15. Emery, S.B.; Franks, J.R. The potential for collaborative agri-environment schemes in England: Can a well-designed collaborative approach address farmers' concerns with current schemes? J. Rural Stud. 2012, 28, 218-231. [CrossRef]

16. Ma, S.; Swinton, S.M.; Lupi, F.; Jolejole-Foreman, C. Farmers' Willingness to Participate in Payment-forEnvironmental-Services Programmes. J. Agric. Econ. 2012, 63, 604-626. [CrossRef]

17. Home, R.; Balmer, O.; Jahrl, I.; Stolze, M.; Pfiffner, L. Motivations for implementation of ecological compensation areas on Swiss lowland farms. J. Rural Stud. 2014, 34, 26-36. [CrossRef]

18. Price, J.C.; Leviston, Z. Predicting pro-environmental agricultural practices: The social, psychological and contextual influences on land management. J. Rural Stud. 2014, 34, 65-78. [CrossRef]

19. Ruto, E.; Garrod, G. Investigating farmers' preferences for the design of agri-environment schemes: A choice experiment approach. J. Environ. Plan. Manag. 2009, 52, 631-647. [CrossRef]

20. Azizi Khalkheili, T.; Zamani, G.H. Farmer participation in irrigation management: The case of Doroodzan Dam Irrigation Network, Iran. Agric. Water Manag. 2009, 96, 859-865. [CrossRef]

21. Polman, N.B.P.; Slangen, L.H.G. Institutional design of agri-environmental contracts in the European Union: The role of trust and social capital. NJAS Wagening. J. Life Sci. 2008, 55, 413-430. [CrossRef]

22. Bjørkhaug, H.; Blekesaune, A. Development of organic farming in Norway: A statistical analysis of neighbourhood effects. Geoforum 2013, 45, 201-210. [CrossRef]

23. Jongeneel, R.A.; Polman, N.B.P.; Slangen, L.H.G. Why are Dutch farmers going multifunctional? Land Use Policy 2008, 25, 81-94. [CrossRef]

24. Raggi, M.; Viaggi, D.; Bartolini, F.; Furlan, A. The role of policy priorities and targeting in the spatial location of participation in Agri-Environmental Schemes in Emilia-Romagna (Italy). Land Use Policy 2015, 47, 78-89. [CrossRef]

25. Knowler, D.; Bradshaw, B. Farmers' adoption of conservation agriculture: A review and synthesis of recent research. Food Policy 2007, 32, 25-48. [CrossRef]

26. De Graaff, J.; Amsalu, A.; Bodnár, F.; Kessler, A.; Posthumus, H.; Tenge, A. Factors influencing adoption and continued use of long-term soil and water conservation measures in five developing countries. Appl. Geogr. 2008, 28, 271-280. [CrossRef]

27. Pannell, D.J.; Marshall, G.R.; Barr, N.; Curtis, A.; Vanclay, F.; Wilkinson, R. Understanding and promoting adoption of conservation practices by rural landholders. Aust. J. Exp. Agric. 2006, 46, 1407-1424. [CrossRef]

28. Prager, K.; Posthumus, H. Adopting sustainable soil management: The role of socio-economic factors. In Proceedings of the 16th Annual International Sustainable Development Research Conference, Hong Kong, China, 30 May-1 June 2010; pp. 1-32. 
29. McKeever, E.; Anderson, A.; Jack, S. Entrepreneurship and mutuality: Social capital in processes and practices. Entrep. Reg. Dev. 2014, 26, 453-477. [CrossRef]

30. Blackstock, K.L.; Ingram, J.; Burton, R.; Brown, K.M.; Slee, B. Understanding and influencing behaviour change by farmers to improve water quality. Sci. Total Environ. 2010, 408, 5631-5638. [CrossRef] [PubMed]

31. Quinn, C.; Burbach, M.E. Personal characteristics preceding pro-environmental behaviors that improve surface water quality. Great Plains Res. 2008, 18, 103-114.

32. Prokopy, L.S.; Floress, K.; Klotthor-Weinkauf, D.; Baumgart-Getz, A. Determinants of agricultural best management practice adoption: Evidence from the literature. J. Soil Water Conserv. 2008, 63, 300-311. [CrossRef]

33. Baumgart-Getz, A.; Prokopy, L.S.; Floress, K. Why farmers adopt best management practice in the United States: A meta-analysis of the adoption literature. J. Environ. Manag. 2012, 96, 17-25. [CrossRef] [PubMed]

34. Wauters, E.; Mathijs, E. The adoption of farm level soil conservation practices in developed countries: A meta-analytic review. Int. J. Agric. Resour. Gov. Ecol. 2014, 10, 78-102. [CrossRef]

35. Padel, S. Conversion to Organic Farming: A Typical Example of the Diffusion of an Innovation? Sociol. Rural. 2001, 41, 40-61. [CrossRef]

36. Lamine, C.; Bellon, S. Conversion to organic farming: A multidimensional research object at the crossroads of agricultural and social sciences. A review. Agron. Sustain. Dev. 2009, 29, 97-112. [CrossRef]

37. Kabii, T.; Horwitz, P. A review of landholder motivations and determinants for participation in conservation covenanting programmes. Environ. Conserv. 2006, 33, 11-20. [CrossRef]

38. Smith, P.; Martino, D.; Cai, Z.; Gwary, D.; Janzen, H.; Kumar, P.; McCarl, B.; Ogle, S.; O’Mara, F.; Rice, C.; et al. Policy and technological constraints to implementation of greenhouse gas mitigation options in agriculture. Agric. Ecosyst. Environ. 2007, 118, 6-28. [CrossRef]

39. Liu, T.; Bruins, R.; Heberling, M. Factors Influencing Farmers' Adoption of Best Management Practices: A Review and Synthesis. Sustainability 2018, 10, 432. [CrossRef] [PubMed]

40. Greiner, R.; Lankester, A. On-farm biodiversity conservation in Australia's tropical savannas: Production trade-offs, impediments, motivators and policy approaches. In Proceedings of the Resource Economics Workshop, Rockhampton, Australia, 28 October 2005; p. 20.

41. Lastra-Bravo, X.B.; Hubbard, C.; Garrod, G.; Tolón-Becerra, A. What drives farmers' participation in EU agri-environmental schemes?: Results from a qualitative meta-analysis. Environ. Sci. Policy 2015, 54, 1-9. [CrossRef]

42. Burton, R.J.F.; Schwarz, G. Result-oriented agri-environmental schemes in Europe and their potential for promoting behavioural change. Land Use Policy 2013, 30, 628-641. [CrossRef]

43. Morrison, M.; Greig, J. Encouraging Participation in Market Based Instruments and Incentive Programs: Literature Review; Impediments to the Uptake of Market Based Instruments; Land \& Water Australia: Camberra, Australia, 2006.

44. Riley, M. Turning Farmers into Conservationists? Progress and Prospects. Geogr. Compass 2011, 5, 369-389. [CrossRef]

45. Zimmermann, A.; Britz, W. European farms' participation in agri-environmental measures. Land Use Policy 2016, 50, 214-228. [CrossRef]

46. Läpple, D.; Rensburg, T. Van Adoption of organic farming: Are there differences between early and late adoption? Ecol. Econ. 2011, 70, 1406-1414. [CrossRef]

47. Brown, P.; Hart, G.; Small, B.; de Oca Munguia, O.M. Agents for diffusion of agricultural innovations for environmental outcomes. Land Use Policy 2016, 55, 318-326. [CrossRef]

48. Varble, S.; Secchi, S.; Druschke, C.G. An Examination of Growing Trends in Land Tenure and Conservation Practice Adoption: Results from a Farmer Survey in Iowa. Environ. Manag. 2016, 57, 318-330. [CrossRef] [PubMed]

49. Ajzen, I. From intentions to action: A theory of planned behavior. In Action Control: From Cognition to Behavior; Kuhl, J., Beckmann, J., Eds.; Springer: Heidelberg, Germany, 1985; pp. 11-39; ISBN 978-3-642-69748-7.

50. Fishbein, M.E.; Ajzen, I. Belief, Attitude, Intention, and Behavior: An Introduction to Theory and Research; Addison-Wesley: Reading, MA, USA, 1975; ISBN 9780201020892.

51. Ajzen, I.; Fishbein, M. The Influence of Attitudes on Behavior. In The Handbook of Attitudes; Albarracin, D., Johnson, B.T., Zanna, M.P., Eds.; Lawrence Erlbaum Associates: Mahwah, NJ, USA, 2005; pp. 173-221; ISBN 9780805844931. 
52. Mettepenningen, E.; Vandermeulen, V.; Delaet, K.; Van Huylenbroeck, G.; Wailes, E.J. Investigating the influence of the institutional organisation of agri-environmental schemes on scheme adoption. Land Use Policy 2013, 33, 20-30. [CrossRef]

53. Burton, M.; Rigby, D.; Young, T. Modelling the adoption of organic horticultural technology in the UK using duration analysis. Aust. J. Agric. Resour. Econ. 2003, 47, 29-54. [CrossRef]

54. Läpple, D.; Kelley, H. Understanding the uptake of organic farming: Accounting for heterogeneities among Irish farmers. Ecol. Econ. 2013, 88, 11-19. [CrossRef]

55. Defrancesco, E.; Perito, M.; Bozzolan, I.; Cei, L.; Stefani, G. Testing Consumers' Preferences for Environmental Attributes of Pasta. Insights from an ABR Approach. Sustainability 2017, 9, 1701. [CrossRef]

56. Levidow, L.; Psarikidou, K. Food Relocalization for Environmental Sustainability in Cumbria. Sustainability 2011, 3, 692-719. [CrossRef]

57. Schaller, L.; Targetti, S.; Villanueva, A.J.; Zasada, I.; Kantelhardt, J.; Arriaza, M.; Bal, T.; Fedrigotti, V.B.; Giray, F.H.; Häfner, K.; et al. Agricultural landscapes, ecosystem services and regional competitiveness-Assessing drivers and mechanisms in nine European case study areas. Land Use Policy 2018, 76, 735-745. [CrossRef]

58. Dupré, M.; Michels, T.; Le Gal, P.-Y. Diverse dynamics in agroecological transitions on fruit tree farms. Eur. J. Agron. 2017, 90, 23-33. [CrossRef]

59. Zasada, I.; Häfner, K.; Schaller, L.; van Zanten, B.T.; Lefebvre, M.; Malak-Rawlikowska, A.; Nikolov, D.; Rodríguez-Entrena, M.; Manrique, R.; Ungaro, F.; Zavalloni, M.; et al. A conceptual model to integrate the regional context in landscape policy, management and contribution to rural development: Literature review and European case study evidence. Geoforum 2017, 82, 1-12. [CrossRef]

60. Bonnet, C.; Bouamra-Mechemache, Z. Organic Label, Bargaining Power, and Profit-sharing in the French Fluid Milk Market. Am. J. Agric. Econ. 2016, 98, 113-133. [CrossRef]

61. Marette, S. Quality, market mechanisms and regulation in the food chain. Bio-Based Appl. Econ. 2017, 5, 217-235. [CrossRef]

62. Schmitt, E.; Barjolle, D.; Tanquerey-Cado, A.; Brunori, G. Sustainability comparison of a local and a global milk value chains in Switzerland. Bio-Based Appl. Econ. 2016, 5, 79-102. [CrossRef]

63. Aramyan, L.H.; Kuiper, M. Analyzing price transmission in agri-food supply chains: An overview. Meas. Bus. Excel. 2009, 13, 3-12. [CrossRef]

64. Routroy, S.; Behera, A. Agriculture supply chain: A systematic review of literature and implications for future research. J. Agribus. Dev. Emerg. Econ. 2017, 7, 275-302. [CrossRef]

65. Bonanno, A.; Russo, C.; Menapace, L. Market power and bargaining in agrifood markets: A review of emerging topics and tools. Agribusiness 2018, 34, 6-23. [CrossRef]

66. Staal, S.J.; Baltenweck, I.; Waithaka, M.M.; DeWolff, T.; Njoroge, L. Location and uptake: Integrated household and GIS analysis of technology adoption and land use, with application to smallholder dairy farms in Kenya. Agric. Econ. 2002, 27, 295-315. [CrossRef]

67. Marenya, P.P.; Barrett, C.B. Household-level determinants of adoption of improved natural resources management practices among smallholder farmers in western Kenya. Food Policy 2007, 32, 515-536. [CrossRef]

68. Anley, Y.; Bogale, A.; Haile-Gabriel, A. Adoption decision and use intensity of soil and water conservation measures by smallholder subsistence farmers in Dedo District, Western Ethiopia. Land Dégrad. Dev. 2007, 18, 289-302. [CrossRef]

69. Pedzisa, T.; Rugube, L.; Winter-Nelson, A.; Baylis, K.; Mazvimavi, K. Abandonment of Conservation Agriculture by Smallholder Farmers in Zimbabwe. J. Sustain. Dev. 2015, 8, 69-82. [CrossRef]

70. Turinawe, A.; Mugisha, J.; Drake, L. Soil and water conservation agriculture in subsistence systems: Determinants of adoption in southwestern Uganda. J. Soil Water Conserv. 2015, 70, 133-142. [CrossRef]

71. Amsalu, A.; de Graaff, J. Determinants of adoption and continued use of stone terraces for soil and water conservation in an Ethiopian highland watershed. Ecol. Econ. 2007, 61, 294-302. [CrossRef]

72. Sidibé, A. Farm-level adoption of soil and water conservation techniques in northern Burkina Faso. Agric. Water Manag. 2005, 71, 211-224. [CrossRef]

73. Burton, M.; Rigby, D.; Young, T. Analysis of the determinants of adoption of organic horticultural techniques in the UK. J. Agric. Econ. 1999, 50, 47-63. [CrossRef] 
74. Mala, Z.; Maly, M. The determinants of adopting organic farming practices: A case study in the Czech Republic. Agric. Econ. Zemed. Èkon. 2013, 59, 19-28. [CrossRef]

75. Genius, M.; Pantzios, C.J.; Tzouvelekas, V. Information Acquisition and Adoption of Organic Farming Practices. J. Agric. Resour. Econ. 2006, 31, 93-113.

76. Juvančič, L.; Travnikar, T.; Glavan, M.; Cvejić, R.; Pintar, M. Targeting and Spatial Impacts of Agri-Environmental Support-Spatial Econometric Analysis of Agri-Environmental Measures in Slovenia. In Proceedings of the 132nd Seminar of the EAAE “Is Transition in European Agriculture Really Over?", Skopje, Republic of Macedonia, 25-27 October 2012; pp. 1-16.

77. Kallas, Z.; Serra, T.; Gil, J.M. Farmers' objectives as determinants of organic farming adoption: The case of Catalonian vineyard production. Agric. Econ. 2010, 41, 409-423. [CrossRef]

78. Démurger, S.; Pelletier, A. Volunteer and satisfied? Rural households' participation in a payments for environmental services programme in Inner Mongolia. Ecol. Econ. 2015, 116, 25-33. [CrossRef]

79. Haghjou, M.; Hayati, B.; Momeni Choleki, D. Identification of Factors Affecting Adoption of Soil Conservation Practices by Some Rainfed Farmers in Iran. J. Agric. Sci. Technol. 2014, 16, 957-967.

80. Lynch, L.; Lovell, S.J. Combining Spatial and Survey Data to Explain Participation in Agricultural Land reservation Programs. Land Econ. 2003, 79, 259-276. [CrossRef]

81. Tenge, A.J.; De Graaff, J.; Hella, J.P. Social and economic factors affecting the adoption of soil and water conservation in West Usambara highlands, Tanzania. Land Dégrad. Dev. 2004, 15, 99-114. [CrossRef]

82. Tafa, K.; Beshah, T.; Amsalu, A.; Resource, N.; Berehan, D.; Berehan, D.; Extension, A.; Dawa, D. Determinants of Physical Soil and Water Conservation Practices in Ethiopia's Semi-Arid Tropics: The Case of Bati District. Soc. Basic Sci. Res. Rev. 2009, 2, 525-541.

83. Kassie, M.; Jaleta, M.; Shiferaw, B.; Mmbando, F.; Mekuria, M. Adoption of interrelated sustainable agricultural practices in smallholder systems: Evidence from rural Tanzania. Technol. Forecast. Soc. Chang. 2013, 80, 525-540. [CrossRef]

84. Lapar, M.L.; Pandey, S. Adoption of soil conservation: The case of the Philippine uplands. Agric. Econ. 1999, 21, 241-256. [CrossRef]

85. Cramb, R.A. The role of social capital in the promotion of conservation farming: The case of 'landcare' in the southern Philippines. Land Dégrad. Dev. 2006, 17, 23-30. [CrossRef]

86. Zbinden, S.; Lee, D.R. Paying for Environmental Services: An Analysis of Participation in Costa Rica's PSA Program. World Dev. 2005, 33, 255-272. [CrossRef]

87. Neill, S.P.; Lee, D.R. Explaining the Adoption and Disadoption of Sustainable Agriculture: The Case of Cover Crops in Northern Honduras. Econ. Dev. Cult. Chang. 2001, 49, 793-820. [CrossRef]

88. Arellanes, P.; Lee, D.R. The Determinants of Adoption of Sustainable Agriculture Technologies: Evidence from the Hillsides of Honduras. In Proceedings of the 25th International Conference of Agricultural Economists (IAAE), Durban, South Africa, 16-22 August 2003; pp. 693-699.

89. Allaire, G.; Cahuzac, E.; Simioni, M. Spatial diffusion and adoption determinants of European agri-environmental supports related to extensive grazing in France. In Proceedings of the 5èmes Journées De Recherche En Sciences Sociales, Dijon, France, 8-9 December 2011; pp. 1-25.

90. Defrancesco, E.; Gatto, P.; Mozzato, D. To leave or not to leave? Understanding determinants of farmers' choices to remain in or abandon agri-environmental schemes. Land Use Policy 2018, 76, 460-470. [CrossRef]

91. Davey, K.A.; Furtan, W.H. Factors that affect the adoption decision of conservation tillage in the prairie region of Canada. Can. J. Agric. Econ. 2008, 56, 257-275. [CrossRef]

92. Duke, J.M. Participation in Agricultural Land Preservation Programs: Parcel Quality and a Complex Policy Environment. Agric. Resour. Econ. Rev. 2004, 33, 34-49. [CrossRef]

93. Koesling, M.; Flaten, O.; Lien, G. Factors influencing the conversion to organic farming in Norway. Int. J. Agric. Resour. 2008, 7, 78-95. [CrossRef]

94. Nkegbe, P.K.; Shankar, B.; Ceddia, G.M. Smallholder Adoption of Soil and Water Conservation Practices in Northern Ghana. In Proceedings of the EAAE 2011 Congress Change and Uncertainty Challenges for Agriculture, Food and Natural Resources, Zurich, Switzerland, 30 August-2 September 2011; pp. 1-12.

95. Khaledi, M.; Weseen, S.; Sawyer, E.; Ferguson, S.; Gray, R. Factors Influencing Partial and Complete Adoption of Organic Farming Practices in Saskatchewan, Canada. Can. J. Agric. Econ. Rev. Can. D'agroecon. 2010, 58, 37-56. [CrossRef] 
96. Ngombe, J.; Kalinda, T.; Tembo, G.; Kuntashula, E. Econometric Analysis of the Factors that Affect Adoption of Conservation Farming Practices by Smallholder Farmers in Zambia. J. Sustain. Dev. 2014, 7, 124-138. [CrossRef]

97. Schmidtner, E.; Lippert, C.; Engler, B.; Haring, A.M.; Aurbacher, J.; Dabbert, S. Spatial distribution of organic farming in Germany: Does neighbourhood matter? Eur. Rev. Agric. Econ. 2012, 39, 661-683. [CrossRef]

98. Yang, A.L.; Rounsevell, M.D.A.; Wilson, R.M.; Haggett, C. Spatial analysis of agri-environmental policy uptake and expenditure in Scotland. J. Environ. Manag. 2014, 133, 104-115. [CrossRef] [PubMed]

99. Pascucci, S.; Capitanio, F.; Adinolfi, F.; De-Magistris, T. Factors Affecting Participation of Italian Farmers in Rural Development Policy. In Proceedings of the 122nd EAAE Seminar “Evidence-Based Agricultural and Rural Policy Making: Methodological and Empirical Challenges of Policy Evaluation", Ancona, Italy, 17-18 February 2011; Volume 40, pp. 605-631.

100. Boncinelli, F.; Bartolini, F.; Brunori, G.; Casini, L. Spatial analysis of the participation in agri-environment measures for organic farming. Renew. Agric. Food Syst. 2016, 31, 375-386. [CrossRef]

101. Soule, M.J.; Tegene, A.; Weibe, K.D. Land Tenure and the Adoption of Conservation Practices. Am. J. Agric. Econ. 2000, 82, 993-1005. [CrossRef]

102. Swinton, S.M. More Social Capital, Less Erosion: Evidence from Peru's Altiplano. In Proceedings of the Annual Meeting of the American Agricultural Economics Association, Tampa, FL, USA, 30 July-2 August 2000; p. 19.

103. Crabtree, B.; Chalmers, N.; Barron, N.-J. Information for Policy Design: Modelling Participation in a Farm Woodland Incentive Scheme. J. Agric. Econ. 1998, 49, 306-320. [CrossRef]

104. Genius, M.; Koundouri, P.; Nauges, C.; Tzouvelekas, V. Information Transmission in Irrigation Technology Adoption and Diffusion: Social Learning, Extension Services, and Spatial Effects. Am. J. Agric. Econ. 2014, 96, 328-344. [CrossRef]

105. Scorzelli, D. La partecipazione Degli Agricoltori alle Misure Agroambientali-Un'analisi Socioeconomica Attraverso le Aziende RICA del Veneto; INEA: Rome, Italy, 2007.

106. Bertoni, D.; Cavicchioli, D.; Pretolani, R.; Olper, A. Agri-Environmental Measures Adoption: New Evidence From Lombardy Region. In Proceedings of the 109th EAAE Seminar "The CAP after the Fischle Reform: National implementations, Impact Assessment and the Agenda for Future Reforms", Viterbo, Italy, 20-21 November 2008; p. 20.

107. Bertoni, D.; Cavicchioli, D.; Pretolani, R.; Olper, A. Agri-environmental measures adoption in Lombardy: Farm, territorial and institutional contraints. In Proceedings of the XLVI Convegno di Studi "Cambiamenti Nel Sistema Alimentare: Nuovi Problemi, Strategie, Politiche", Piacenza, Italy, 16-19 September 2009; pp. 1-18.

108. Bertoni, D.; Cavicchioli, D.; Pretolani, R.; Olper, A. Determinants of agri-environmental measures adoption: Do institutional constraints matter? Environ. Econ. 2012, 3, 8-19.

109. Finger, R.; Lehmann, B. Adoption of Agri-environmental Programmes in Swiss Crop Production. EuroChoices 2012, 11, 28-33. [CrossRef]

110. Micha, E.; Areal, F.J.; Tranter, R.B.; Bailey, A.P. Uptake of agri-environmental schemes in the Less-Favoured Areas of Greece: The role of corruption and farmers' responses to the financial crisis. Land Use Policy 2015, 48, 144-157. [CrossRef]

111. Capitanio, F.; Adinolfi, F.; Malorgio, G. What explains farmers' participation in Rural Development Policy in Italian southern region? An empirical analysis. New Medit 2011, 10, $19-24$.

112. Meraner, M.; Heijman, W.; Kuhlman, T.; Finger, R. Determinants of farm diversification in the Netherlands. Land Use Policy 2015, 42, 767-780. [CrossRef]

113. Murphy, G.; Hynes, S.; Murphy, E.; O’Donoghue, C. An investigation into the type of farmer who chose to participate in Rural Environment Protection Scheme (REPS) and the role of institutional change in influencing scheme effectiveness. Land Use Policy 2014, 39, 199-210. [CrossRef]

114. Scozzafava, G.; Pagnotta, G.; Contini, C.; Casini, L. What Farm Features determine the Granting of RDP Funding? The Case of Measures 121 and 214 in Tuscany. Qual. Access Success 2014, 15, 74-78.

115. Mzoughi, N. Farmers adoption of integrated crop protection and organic farming: Do moral and social concerns matter? Ecol. Econ. 2011, 70, 1536-1545. [CrossRef]

116. Grammatikopoulou, I.; Pouta, E.; Myyrä, S. Exploring the determinants for adopting water conservation measures. What is the tendency of landowners when the resource is already at risk? J. Environ. Plan. Manag. 2015, 1-22. [CrossRef] 
117. Unay Gailhard, I.; Bavorová, M.; Pirscher, F. Adoption of Agri-Environmental Measures by Organic Farmers: The Role of Interpersonal Communication. J. Agric. Educ. Ext. 2014, 21, 127-148. [CrossRef]

118. Unay Gailhard, I.; Bojnec, Š. Farm size and participation in agri-environmental measures: Farm-level evidence from Slovenia. Land Use Policy 2015, 46, 273-282. [CrossRef]

119. Borsotto, P.; Henke, R.; Macrì, M.C.; Salvioni, C. Participation in rural landscape conservation schemes in Italy. Landsc. Res. 2008, 33, 347-363. [CrossRef]

120. Barreiro-Hurlé, J.; Espinosa-Goded, M.; Dupraz, P. Does intensity of change matter? Factors affecting adoption of agri-environmental schemes in Spain. In Proceedings of the 107th EAAE Seminar "Modelling of Agricultural and Rural Development Policies", Sevilla, Spain, 29 January-1 February 2008; Volume 53, pp. 891-905.

121. Damianos, D.; Giannakopoulos, N. Farmers' participation in agri-environmental schemes in Greece. Br. Food J. 2002, 104, 261-273. [CrossRef]

122. Wynn, G.; Crabtree, B.; Potts, J. Modelling Farmer Entry into the Environmentally Sensitive Area Schemes in Scotland. J. Agric. Econ. 2001, 52, 65-82. [CrossRef]

123. Söderqvist, T. Are farmers prosocial? Determinants of the willingness to participate in a Swedish catchment-based wetland creation programme. Ecol. Econ. 2003, 47, 105-120. [CrossRef]

124. Calatrava Leyva, J.; Franco Martínez, J.A.; González Roa, M.C. Analysis of the adoption of soil conservation practices in olive groves: The case of mountainous areas in southern Spain. Span. J. Agric. Res. 2007, 5, 249-258. [CrossRef]

125. Habron, G.B. Adoption of conservation practices by agricultural landowners in three Oregon watersheds. J. Soil Water Conserv. 2004, 59, 109-115.

126. Anderson, J.B.; Jolly, D.A.; Green, R. Determinants of farmer adoption of organic production methods in the fresh-market produce sector in California: A logistic regression analysis. Western Agricultural Economics Association Annual Meeting, San Francisco, CA, USA, 6-8 July 2005; p. 25.

127. Neupane, R.P.; Sharma, K.R.; Thapa, G.B. Adoption of agroforestry in the hills of Nepal: A logistic regression analysis. Agric. Syst. 2002, 72, 177-196. [CrossRef]

128. Unay Gailhard, I.; Bavorova, M.; Pirscher, F. The Influence of Communication Frequency with Social Network Actors on the Continuous Innovation Adoption: Organic Farmers in Germany. In Proceedings of the 131st EAAE Seminar "Innovation for Agricultural Competitiveness and Sustainability of Rural Areas", Prague, Czech Republic, 18-19 September 2012; pp. 1-19.

129. Lokhorst, A.M.; Hoon, C.; le Rutte, R.; de Snoo, G. There is an I in nature: The crucial role of the self in nature conservation. Land Use Policy 2014, 39, 121-126. [CrossRef]

130. Giovanopoulou, E.; Nastis, S.A.; Papanagiotou, E. Modeling farmer participation in agri-environmental nitrate pollution reducing schemes. Ecol. Econ. 2011, 70, 2175-2180. [CrossRef]

131. Mishra, A.K.; Khanal, A.R. Is participation in agri-environmental programs affected by liquidity and solvency? Land Use Policy 2013, 35, 163-170. [CrossRef]

132. Chen, X.; Lupi, F.; An, L.; Sheely, R.; Viña, A.; Liu, J. Agent-based modeling of the effects of social norms on enrollment in payments for ecosystem services. Ecol. Model. 2012, 229, 16-24. [CrossRef] [PubMed]

133. Karki, L.; Schleenbecker, R.; Hamm, U. Factors influencing a conversion to organic farming in Nepalese tea farms. J. Agric. Rural Dev. Trop. Subtrop. 2011, 112, 113-123.

134. Yuan, Y.; Liu, Y.; Hu, Y.; Chen, X.; Peng, J. Identification of Non-economic Influencing Factors Affecting Farmer's Participation in the Paddy Landto-Dry Land Program in Chicheng County, China. Sustainability 2017, 9, 366. [CrossRef]

135. Dimara, E.; Skuras, D. Adoption of agricultural innovations as a two-stage partial observability process. Agric. Econ. 2003, 28, 187-196. [CrossRef]

136. Hattam, C. Adopting Organic Agriculture: An Investigation Using the Theory of Planned Behaviour. In Proceedings of the International Association of Agricultural Economics Conference, Gold Coast, Australia, 12-19 August 2006; p. 16.

137. D’Emden, F.H.; Llewellyn, R.S.; Burton, M.P. Factors influencing adoption of conservation tillage in Australian cropping regions. Aust. J. Agric. Resour. Econ. 2008, 52, 169-182. [CrossRef]

138. Arslan, A.; McCarthy, N.; Lipper, L.; Asfaw, S.; Cattaneo, A. Adoption and intensity of adoption of conservation farming practices in Zambia. Agric. Ecosyst. Environ. 2014, 187, 72-86. [CrossRef] 
139. Chiputwa, B.; Langyintuo, A.S.; Wall, P. Adoption of Conservation Agriculture Technologies by Smallholder Farmers in the Shamva District of Zimbabwe: A Tobit application. In Proceedings of the 2011 Meeting of the Southern Agricultural Economics Association (SAEA), Corpus Christi, TX, USA, 5-8 February 2011; p. 28.

140. Lee, S.; Nguyen, T.; Poppenborg, P.; Shin, H.-J.; Koellner, T. Conventional, Partially Converted and Environmentally Friendly Farming in South Korea: Profitability and Factors Affecting Farmers' Choice. Sustainability 2016, 8, 704. [CrossRef]

141. Tiffin, R.; Balcombe, K. The determinants of technology adoption by UK farmers using Bayesian model averaging: The cases of organic production and computer usage. Aust. J. Agric. Resour. Econ. 2011, 55, 579-598. [CrossRef]

142. Mazvimavi, K.; Twomlow, S. Socioeconomic and institutional factors influencing adoption of conservation farming by vulnerable households in Zimbabwe. Agric. Syst. 2009, 101, 20-29. [CrossRef]

143. Wollni, M.; Andersson, C. Spatial patterns of organic agriculture adoption: Evidence from Honduras. Ecol. Econ. 2014, 97, 120-128. [CrossRef]

144. Thangata, P.H.; Alavalapati, J.R.R. Agroforestry adoption in southern Malawi: The case of mixed intercropping of Gliricidia sepium and maize. Agric. Syst. 2003, 78, 57-71. [CrossRef]

145. Unay Gailhard, I.; Bojnec, Š. Farmland use size and the adoption of agri-environmental measures: Farm-level evidence from Slovenia. In Proceedings of the 17th European Roundtable on Sustainable Consumption and Production, Portorož, Slovenia, 14-16 October 2014; p. 315.

146. Zanella, M.A.; Schleyer, C.; Speelman, S. Why do farmers join Payments for Ecosystem Services (PES) schemes? An Assessment of PES water scheme participation in Brazil. Ecol. Econ. 2014, 105, 166-176. [CrossRef]

147. Luzar, E.J.; Diagne, A. Participation in the next generation of agriculture conservation programs: The role of environmental attitudes. J. Socio-Econ. 1999, 28, 335-349. [CrossRef]

148. Bartolini, F.; Raggi, M.; Viaggi, D. A spatial analysis of participation in RDP measures: A case study in Emilia Romagna Region. In Proceedings of the 1st AIEAA Conference “Towards a Sustainable Bio-economy: Economic Issues and Policy Challenges", Trento, Italy, 4-5 June 2012; p. 13.

149. Gebrelibanos, T.; Assen, M. Farmers' attitudes towards land resource conservation and its implication for sustainable land management in the Hirmi watershed, Northern Highlands of Ethiopia. J. Sustain. Dev. Africa 2013, 15, 43-55.

150. Bartolini, F.; Latruffe, L.; Viaggi, D. Assessing the effect of the CAP on farm innovation adoption. An analysis in two French regions. In Proceedings of the 122nd EAAE Seminar "Evidence-Based Agricultural and Rural Policy Making: Methodological and Empirical Challenges of Policy Evaluation", Ancona, Italy, 17-18 February 2011; p. 13.

151. Greiner, R.; Patterson, L.; Miller, O. Motivations, risk perceptions and adoption of conservation practices by farmers. Agric. Syst. 2009, 99, 86-104. [CrossRef]

152. Gardebroek, C. Comparing risk attitudes of organic and non-organic farmers with a Bayesian random coefficient model. Eur. Rev. Agric. Econ. 2006, 33, 485-510. [CrossRef]

153. Baidu-Forson, J. Factors influencing adoption of land-enhancing technology in the Sahel: Lessons from a case study in Niger. Agric. Econ. 1999, 20, 231-239. [CrossRef]

154. Tosakana, N.S.P.; Van Tassell, L.W.; Wulfhorst, J.D.; Boll, J.; Mahler, R.; Brooks, E.S.; Kane, S. Determinants of the adoption of conservation practices by farmers in the Northwest Wheat and Range Region. J. Soil Water Conserv. 2010, 65, 404-412. [CrossRef]

155. Mathijs, E. Social capital and farmers' willingness to adopt countryside stewardship schemes. Outlook Agric. 2003, 32, 13-16. [CrossRef]

156. Guillem, E.E.; Barnes, A. Farmer perceptions of bird conservation and farming management at a catchment level. Land Use Policy 2013, 31, 565-575. [CrossRef]

157. Dedeurwaerdere, T.; Polard, A.; Melindi-Ghidi, P. The role of network bridging organisations in compensation payments for agri-environmental services under the EU Common Agricultural Policy. Ecol. Econ. 2015, 119, 24-38. [CrossRef] [PubMed]

158. Rezvanfar, A.; Samiee, A.; Faham, E. Analysis of Factors Affecting Adoption of Sustainable Soil Conservation Practices among Wheat Growers. World Appl. Sci. J. 2009, 6, 644-651.

159. Greiner, R. Motivations and attitudes influence farmers' willingness to participate in biodiversity conservation contracts. Agric. Syst. 2015, 137, 154-165. [CrossRef] 
160. Page, G.; Bellotti, B. Farmers value on-farm ecosystem services as important, but what are the impediments to participation in PES schemes? Sci. Total Environ. 2015, 515-516, 12-19. [CrossRef] [PubMed]

161. Pérez Urdiales, M.; Lansink, A.O.; Wall, A. Eco-efficiency Among Dairy Farmers: The Importance of Socio-economic Characteristics and Farmer Attitudes. Environ. Resour. Econ. 2016, 64, 559-574. [CrossRef]

162. Van Eeden, M.; Korsten, L. Factors determining use of biological disease control measures by the avocado industry in South Africa. Crop Prot. 2013, 51, 7-13. [CrossRef]

163. Van Hulst, F.J.; Posthumus, H. Understanding (non-) adoption of Conservation Agriculture in Kenya using the Reasoned Action Approach. Land Use Policy 2016, 56, 303-314. [CrossRef]

164. Chouichom, S.; Yamao, M. Comparing Opinions and Attitudes of Organic and Non-Organic Farmers Towards Organic Rice Farming System in North-Eastern Thailand. J. Org. Syst. 2010, 5, 25-35.

165. Salazar, C.; Rand, J. Production risk and adoption of irrigation technology: Evidence from small-scale farmers in Chile. Latin Am. Econ. Rev. 2016, 25. [CrossRef]

166. Fentie, D.; Fufa, B.; Bekele, W. Determinants of the Use of Soil Conservation Technologies by Smallholder Farmers: The Case of Hulet Eju Enesie District, East Gojjam Zone, Ethiopia. Asian J. Agric. Food Sci. 2013, 1, 119-138.

167. D'Emden, F.H.; Llewellyn, R.S.; Burton, M.P. Adoption of conservation tillage in Australian cropping regions: An application of duration analysis. Technol. Forecast. Soc. Chang. 2006, 73, 630-647. [CrossRef]

168. Asafu-Adjaye, J. Factors Affecting the Adoption of Soil Conservation Measures: A Case Study of Fijian Cane Farmers. J. Agric. Resour. Econ. 2008, 33, 99-117.

169. Ajzen, I.; Fishbein, M.E. Understanding Attitudes and Predicting Social Behavior; Prentice Hall: Englewood Cliffs, NJ, USA; New York, NY, USA, 1980.

170. Welch, E.W.; Marc-Aurele, F.J. Determinants of Farmer Behavior: Adoption of and Compliance with Best Management Practices for Nonpoint Source Pollution in the Skaneateles Lake Watershed. Lake Reserv. Manag. 2001, 17, 233-245. [CrossRef]

171. Pietola, K.S.; Lansink, A.O. Farmer response to policies promoting organic farming technologies in Finland. Eur. Rev. Agric. Econ. 2001, 28, 1-15. [CrossRef]

172. Mann, S. Farm Size Growth and Participation in Agri-environmental Schemes: A Configural Frequency Analysis of the Swiss Case. J. Agric. Econ. 2005, 56, 373-384. [CrossRef]

173. Arriagada, R.A.; Sills, E.O.; Pattanayak, S.K.; Ferraro, P.J. Combining Qualitative and Quantitative Methods to Evaluate Participation in Costa Rica's Program of Payments for Environmental Services. J. Sustain. For. 2009, 28, 343-367. [CrossRef]

174. Van Thanh, N.; Yapwattanaphun, C. Banana Farmers' Adoption of Sustainable Agriculture Practices in the Vietnam Uplands: The Case of Quang Tri Province. Agric. Agric. Sci. Procedia 2015, 5, 67-74. [CrossRef]

175. Murphy, G.; Hynes, S.; Murphy, E.; O’Donoghue, C.; Green, S. Assessing the compatibility of farmland biodiversity and habitats to the specifications of agri-environmental schemes using a multinomial logit approach. Ecol. Econ. 2011, 71, 111-121. [CrossRef]

176. Timprasert, S.; Datta, A.; Ranamukhaarachchi, S.L. Factors determining adoption of integrated pest management by vegetable growers in Nakhon Ratchasima Province, Thailand. Crop Prot. 2014, 62, 32-39. [CrossRef]

(C) 2018 by the authors. Licensee MDPI, Basel, Switzerland. This article is an open access article distributed under the terms and conditions of the Creative Commons Attribution (CC BY) license (http://creativecommons.org/licenses/by/4.0/). 